\title{
Penerapan Metode Dempster Shafer Dalam Mendiagnosa Penyakit Faringitis
}

\author{
Pauji Safri Hasibuan, M. Iqbal Batubara \\ Program Studi Teknik Informatika, STMIK Budi Darma, Medan, Indonesia \\ Jalan Sisingamangaraja No. 338 Simp Limun, Medan, Indonesia
}

\begin{abstract}
Abstrak
Faringitis adalah suatu penyakit peradangan yang menyerang tenggorok atau hulu kerongkongan. Kadang juga disebut sebagai radang tenggorokan. Radang ini bisa disebabkan oleh virus atau bakteri streptococcus. Infeksi virus biasanya merupakan penyebab selesma (pilek) dan influenza yang kemudian mengakibatkan terjadinya radang tenggorokan. Teori Dempster Shafer adalah suatu teori matematika untuk pembuktian berdasarkan belieffunctions and plausible reasoning (fungsi kepercayaan dan pemikiran yang masuk akal), yang digunakan untuk mengkombinasikan potongan informasi yang terpisah (bukti) untuk mengkalkulasi kemungkinan dari suatu peristiwa
\end{abstract}

Kata Kunci: Sistem Pakar, Faringitis, Dempster Shafer

\section{Abstract}

Pharyngitis is an inflammatory disease that attacks the throat or upstream of the esophagus. Sometimes also called a sore throat. This inflammation can be caused by a virus or streptococcus bacteria. Viral infections are usually the cause of colds and influenza which then results in inflammation of the throat. Dempster Shafer Theory is a mathematical theory for proof based on belief functions and plausible reasoning, which is used to combine separate pieces of information (evidence) to calculate the probability of an event

Keywords: Expert System, Pharyngitis, Dempster Shafer

\section{PENDAHULUAN}

Faringitis adalah suatu penyakit peradangan yang menyerang tenggorok atau hulu kerongkongan. Kadang juga disebut sebagai radang tenggorokan. Radang ini bisa disebabkan oleh virus atau bakteri streptococcus. Infeksi virus biasanya merupakan penyebab selesma (pilek) dan influenza yang kemudian mengakibatkan terjadinya radang tenggorokan. Penyakit radang tenggorokan ini biasanya dikenali adanya dinding tenggorokan menebal atau bengkak, berwarna lebih merah, ada bintik - bintik putih dan terasa sakit bila menelan makanan. Untuk melakukan diagnosa gejala penyakit faringitis terdapat langkah - langkah yang harus dijalankan agar kita bisa memastikan hasil diagnosa dengan baik. Tetapi dalam penelitian ini penulis hanya mengumpulkan data - data untuk dianalisa menggunakan sistem pakar. Diagnosa dilakukan untuk mengetahui apakah seseorang mengalami penyakit faringitis. Untuk melakukan diagnosa dilakukan dengan menggunakan metode dempster shafer.

Metode dempster shafer merupakan salah satu metode dalam cabang ilmu matematika dan biasa digunakan untuk menghitung probabilitas. Teori ini digunakan untuk mengkombinasikan potongan informasi yang terpisah untuk mengkalkulasikan kemungkinan dari suatu peristiwa. Teori ini dikembangkan oleh Arthur P. Dempster dan Glenn Shafer. Dalam menghadapi suatu permasalahan, sering ditemukan jawaban yang tidak memiliki kepastian penuh. Ketidakpastian ini dapat berupa hasil suatu kejadian. Hasil yang tidak pasti disebabkan oleh beberapa faktor, yaitu aturan yang tidak pasti dan jawaban pengguna yang tidak pasti atas suatu pertanyaan yang diajukan oleh sistem. Hal ini sangat mudah dilihat pada sistem diagnosis gangguan, dimana pakar tidak dapat mendefinisikan hubungan antara gejala dengan penyebabnya secara pasti, dan pasien tidak dapat merasakan suatu gejala dengan pasti pula. Pada akhirnya akan ditemukan banyak kemungkinan diagnosis. Dempster shafer merupakan nilai parameter klinis yang diberikan untuk menunjukkan besarnya kepercayaan.

Pada tahun 2010 dilakukan penelitian tentang pemanfaatan teori bukti dempster shafer untuk optimalisasi penggunaan lahan berdasarkan data spasial dan citra multi sumber, dan hasil dari penelitian ini membuktikan bahwa modifikasi teori dempster shafer dapat menjadikan klasifikasi penggunaan lahan lebih optimal[1].

Kemudian pada tahun 2013 dilakukan penelitian tentang sistem pakar untuk mendiagnosa penyakit saluran pencernaan menggunakan metode dempster shafer, dan menghasilkan perangkat lunak yang mampu mendiagnosa penyakit saluran pencernaan pada manusia berdasarkan gejala yang dimasukkan dan dapat memberikan data mengenai penyakit yang diderita berupa nama dan defenisi penyakit, penyebab, solusi yang dilengkapi dengan nilai persentase dari penyakit tersebut[2].

Pada tahun yang sama dilakukan penelitian tentang prototype sistem pakar untuk mendeteksi tingkat resiko penyakit jantung kroner dengan metode dempster shafer, dan menghasilkan hasil diagnosa penyakit jantung kroner yang dihasilkan oleh sistem pakar sama dengan hasil perhitungan secara manual dengan menggunakan teori mesin inferensi dempster shafer[3].

Selanjutnya pada tahun 2014 dilakukan penelitian tentang sistem pakar diagnosa penyakit pada tanaman kelapa sawit dengan metode dempster shafer, dan menghasilkan nilai kepercayaan yang dihasilkan dari sistem ini sama dengan hasil perhitungan secara manual dengan menggunakan teori dempster shafer. Sehingga keakuratan hasilnya sudah sesuai dengan perhitungan yang diharapkan[4]. 
Setelah itu pada tahun 2015 dilakukan penelitian tentang penerapan sistem pakar untuk mengidentifikasi masalah kehamilan dengan metode dempster shafer, dan hasil implementasi yang dilkukan berdasarkan tahap pengujian sistem yang dirancang menunjukkan bahwa sitem pakar ini sudah memenuhi kebutuhan responden dengan nilai rata - rata $81,2 \%[5]$.

\section{TEORITIS}

\subsection{Sistem Pakar}

Sistem pakar adalah sistem yang berusaha mengadopsi pengetahuan manusia ke komputer agar komputer dapat menyelesaikan masalah seperti yang biasa dilakukan oleh para ahli. Sistem pakar yang pertama kali muncul adalah General purpose Problem Solver (GPS) dikembangkan oleh Newel Dan Simon. Beberapa definisi yang ada untuk sistem pakar [6][9-11]:

a. Menurut Martin dan Oxman : Sistem pakar adalah sistem berbasis computer yang menggunakan pengetahuan, fakta, dan teknik penalaran dalam memecahkan masalah, yang biasanya hanya dapat diselesaikan oleh seorang pakar dalam bidang tertentu.

b. Menurut Ignizio : Sistem pakar merupakan bidang yang dicirikan oleh system berbasis pengetahuan (Knowledge Base System), memungkinkan adanya komponen untuk berpikir dan mengambil kesimpulan dari sekumpulan kaidah.

c. Menurut Giarratano dan Riley : Sistem pakar adalah salah satu cabang kecerdasan buatan yang menggunakan pengetahuan-pengetahuan khusus yang dimiliki oleh seorang ahli untuk menyelesaikan suatu masalah tertentu.

\subsection{Faringitis}

Faringitis adalah sebuah penyakit yang menyerang tenggorokan atau faring. Kadangkala juga disebut sebagai radang tenggorokan. Radang ini bisa disebabkan oleh virus atau kuman, disebabkan daya tahan yang lemah. Pengobatan dengan antibiotika hanya efektif apabila karena terkena kuman. Kadangkala makan makanan yang sehat dengan buah-buahan yang banyak, disertai dengan vitamin bisa menolong.

Gejala radang tenggorokan seringkali merupakan pertanda penyakit flu atau pilek. Jika sakit di bagian tenggorokan, batuk, susah bernapas, dan kadang disertai demam, pastilah kita menyebutnya radang tenggorokan. Padahal, dengan keluhan tersebut, ada 3 bagian atau organ sekitar tenggorokan yang harus diwaspadai.

1. Tenggorokan (faring)

2. Adenoid yang berada di belakang hidung, dan

3. Sepasang amandel di kiri dan kanan tenggorokan (tonsil palatina).

Ada tiga penyebab radang tenggorokan yang gejalanya dapat berupa rasa sakit di bagian tersebut, susah menelan, susah bernapas, batuk, dan demam.

\subsection{Dempster Shafer}

Metode dempster shafer merupakan salah satu metode dalam cabang ilmu matematika dan biasa digunakan untuk menghitung probabilitas. Teori ini digunakan untuk mengkombinasikan potongan informasi yang terpisah untuk mengkalkulasikan kemungkinan dari suatu peristiwa. Teori ini dikembangkan oleh Arthur P. Dempster dan Glenn Shafer[8]. Dalam menghadapi suatu permasalahan, sering ditemukan jawaban yang tidak memiliki kepastian penuh. Ketidakpastian ini dapat berupa hasil suatu kejadian. Hasil yang tidak pasti disebabkan oleh beberapa faktor, yaitu aturan yang tidak pasti dan jawaban pengguna yang tidak pasti atas suatu pertanyaan yang diajukan oleh sistem. Hal ini sangat mudah dilihat pada sistem diagnosis gangguan, dimana pakar tidak dapat mendefinisikan hubungan antara gejala dengan penyebabnya secara pasti, dan pasien tidak dapat merasakan suatu gejala dengan pasti pula. Pada akhirnya akan ditemukan banyak kemungkinan diagnosis. Dempster shafer merupakan nilai parameter klinis yang diberikan untuk menunjukkan besarnya kepercayaan. Secara umum teori dempster shafer ditulis dalam suatu interval (belief, plausibility). Belief adalah ukuran kekuatan evidence dalam mendukung suatu himpunan proposisi, Dimana nilai bel $(\mathrm{m})$ yaitu $(0$ - 0,9). Plausibility $(\mathrm{pl})$ dinotasikan sebagai $\mathrm{pl}(\mathrm{s})=1-$ bel $(-\mathrm{s})$. Berikut rumus dari teori dempster shafer :

$$
\mathrm{M} 3(\mathrm{z})=\frac{\sum X \cap Y=\mathrm{Z}^{\mathrm{m} 1(\mathrm{X}) \cdot \mathrm{m} 2(\mathrm{Y})}}{1-\sum X \cap Y=\Phi^{\mathrm{m} 1(\mathrm{X}) \cdot \mathrm{m} 2(\mathrm{Y})}}
$$

Keterangan :

M1 = densitas untuk gejala pertama

M2 = densitas untuk gejala kedua

M3 = kombinasi dari kedua densitas diatas

$\Theta=$ semesta pembicaraan dari sekumpulan hipotesis $\left(X^{\prime}\right.$ dan $\left.Y^{\prime}\right)$

$\mathrm{X}$ dan $\mathrm{Y}=$ subset dari $\mathrm{Z}$

$X^{\prime}$ dan $Y^{\prime}=$ subset dari $\theta$ 


\section{ANALISA DAN PEMBAHASAN}

Representasi pengetahuan merupakan metode yang digunakan untuk pengkodean pengetahuan (knowledge base) dalam sistem pakar. Dalam penelitian skripsi ini digunakan metode representasi pengetahuan dengan metode kaidah produksi (production rule). berikut:

Kaidah produksi ini dipilih untuk merepresentasikan pengetahuan karena mempunyai keuntungan sebagai

1. Kaidah produksi terbentuk modular sehingga mempunyai fleksibilitas yang memungkinkan setiap kaidah dapat dimodifikasi dengan mudah.

2. Kaidah produksi merupakan merupakan jenis representasi pengetahuan yang mudah dimengerti dan diinterpretasikan

3. Kaidah produksi menirukan cara berpikir manusia untuk menyelesaikan masalah

4. Kaidah produksi sangat berguna untuk membuat representasi pengetahuan deklaratif

Dalam perancangan data, akan dijelaskan bagaimana data-data yang terdapat dalam sistem sesuai dengan fungsinya sebagai data input ataupun data output sistem.

Tabel 1. Data Penyakit

\begin{tabular}{cc}
\hline $\begin{array}{c}\text { Kode Jenis } \\
\text { Penyakit }\end{array}$ & Jenis Penyakit \\
\hline P1 & Faringitis Virus \\
P2 & Faringitis Streptokokus \\
\hline
\end{tabular}

Tabel 2. Data Gejala

\begin{tabular}{ccc}
\hline No & Kode Gejala & Gejala \\
\hline 1 & GP1 & Nyeri di Kepala \\
2 & GP2 & Demam \\
3 & GP3 & Mual \\
4 & GP4 & Batuk \\
5 & GP5 & Hidak Bergairah \\
6 & GP6 & Suara Serak \\
7 & GP7 & Demam Tinggi \\
8 & GP8 & Nyeri di Perut \\
9 & GP9 & Muntah - Muntah \\
10 & GP10 & Susah Bernafas \\
11 & GP11 & Sakit Saat Menelan \\
12 & GP12 &
\end{tabular}

Tabel 3. Tabel Keputusan

\begin{tabular}{ccc}
\hline Kode Gejala & P1 & P2 \\
\hline GP1 & $\sqrt{ }$ & \\
GP2 & $\sqrt{ }$ & \\
GP3 & $\sqrt{ }$ & \\
GP4 & $\sqrt{ }$ & \\
GP5 & $\sqrt{ }$ & \\
GP6 & $\sqrt{ }$ & $\sqrt{ }$ \\
GP7 & $\sqrt{ }$ & $\sqrt{ }$ \\
GP8 & & $\sqrt{ }$ \\
GP9 & & $\sqrt{ }$ \\
GP10 & & \\
GP11 & & \\
GP12 & Tabel 4. Rentang Nilai & 0.8 \\
& Gejala & 0.6 \\
\hline Kode Gejala & Nyeri di kepala & 0.4 \\
\hline GP1 & Demam & 0.3 \\
GP2 & Mual & 0.1 \\
GP3 & Batuk &
\end{tabular}




\begin{tabular}{clc}
\hline Kode Gejala & \multicolumn{1}{c}{ Gejala } & Bobot \\
\hline GP6 & Hidung Beringus & 0.1 \\
GP7 & Suara Serak & 0.05 \\
GP8 & Demam Tinggi & 0,9 \\
GP9 & Nyeri di Perut & 0,7 \\
GP10 & Muntah - Muntah & 0,5 \\
GP11 & Susah Bernafas & 0,2 \\
GP12 & Sakit Saat Menelan & 0,2 \\
\hline
\end{tabular}

Dari data penyakit dan gejala tersebut di atas dapat drepresentasikan seperti rule dibawah ini. Representasi pengetahuan ini digunakan untuk menentukan proses pencarian atau menentukan kesimpulan dari diagnosa. Berikut adalah pembahasannya.

\section{Rule penyakit Faringitis Virus}

If demam

And nyeri di kepala

And mual

And tidak bergairah

And batuk

And hidung beringus

And suara serak

Then Faringitis Virus

\section{Rule penyakit Faringitis Streptokokus}

If demam tinggi

And nyeri di perut

And muntah - muntah

And susah bernafas

And sakit saat menelan

Then Faringitis Streptokokus

\subsection{Penerapan Dempster Shafer}

Dalam menghadapi suatu permasalahan sering ditemukan jawaban yang tidak memiliki kepastian penuh. Ketidakpastian ini dapat berupa hasil suatu kejadian. Hasil yang tidak pasti disebabkan oleh beberapa faktor, yaitu aturan yang tidak pasti dan jawaban pengguna yang tidak pasti atas suatu pertanyaan yang diajukan oleh sistem. Hal ini sangat mudah dilihat pada sistem diagnosis penyakit, dimana Farigitis tidak dapat mendefinisikan hubungan antara gejala dengan penyebabnya secara pasti, dan pasien tidak dapat merasakan suatu gejala dengan pasti pula. Pada akhirnya akan ditemukan banyak kemungkinan diagnosis. Dempster Shafer merupakan nilai parameter klinis yang diberikan untuk menunjukkan besarnya kepercayaan. Dempster Shefer menunjukkan ukuran kepastian terhadap suatu fakta atau aturan.

Pada Contoh dibawah ini, akan di cari persentase kemungkinan dari gangguan penyakit Faringitis dengan menggunakan perhitungan pada table dibawah ini :

Tabel 5. Contoh Gejala Pilihan

\begin{tabular}{|c|c|c|c|}
\hline No & Kode Gejala & Gejala & BOBOT \\
\hline 1 & GP4 & Batuk & 0,3 \\
\hline 2 & GP10 & Muntah - Muntah & 0,5 \\
\hline
\end{tabular}

Maka

Untuk menghitung nilai Dempster Shafer (DS) Faringitis yang dipilih dengan menggunakan bobot yang telah ditentukan pada setiap gejala

Gejala

$$
\begin{aligned}
\text { Makak : GP4 } & =0,3 \\
\text { GP4 } & 1-0,3 \\
& =0,7
\end{aligned}
$$

Gejala 2

$$
\begin{aligned}
\text { Muntah - Muntah } & \\
\text { Maka : GP10 } & =0,5 \\
\text { GP10 } & =1-0,5 \\
& =0,5
\end{aligned}
$$

Maka untuk menghitung densitas baru untuk beberapa kombinasi M3 digunakan rumus:

$\mathrm{M} 3(\mathrm{Z})=\sum \mathrm{X} \cap \mathrm{Y}=\mathrm{Zm} 1(\mathrm{x}) \cdot \mathrm{m} 2(\mathrm{y})$ 


$$
1-\sum \mathrm{X} \cap \mathrm{Y}=\theta \mathrm{m} 1(\mathrm{x}) \cdot \mathrm{m} 2(\mathrm{y})
$$

Maka nilai dari gejala diatas adalah :

$$
\begin{aligned}
\text { M3 } & =\frac{0,3 * 0,5}{1-(0,7 * 0,5)} \\
\text { M3 } & =\frac{0,15}{1-0,35} \\
\text { M3 } & =\frac{0,15}{0,65} \\
\text { M3 } & =0,23
\end{aligned}
$$

Maka nilai densitas dari kedua gejala tersebut adalah 0,23. Artinya dari pilihan gejala yang telah dipilih diperoleh kesimpulan bahwa pasien tersebut mengalami kemungkinan penyakit Faringitis Virus.

\section{IMPLEMENTASI}

Implementasi merupakan langkah yang digunakan untuk mengoperasikan sistem yang dibangun. Dalam bagian ini dijelaskan bagaimana menjalankan sistem tersebut.

\section{Form Login}

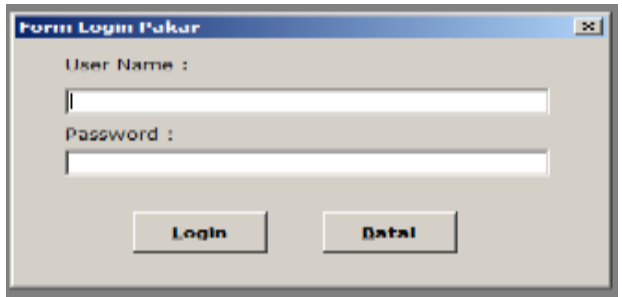

Gambar 1. Form Login

\section{Form Gejala Penyakit}

Input Gejala Penyakit dapat dilakukan dengan cara memilih menu "Pakar" kemudian memilih "Form Data Gejala Penyakit" seperti terlihat pada Gambar dibawah ini :

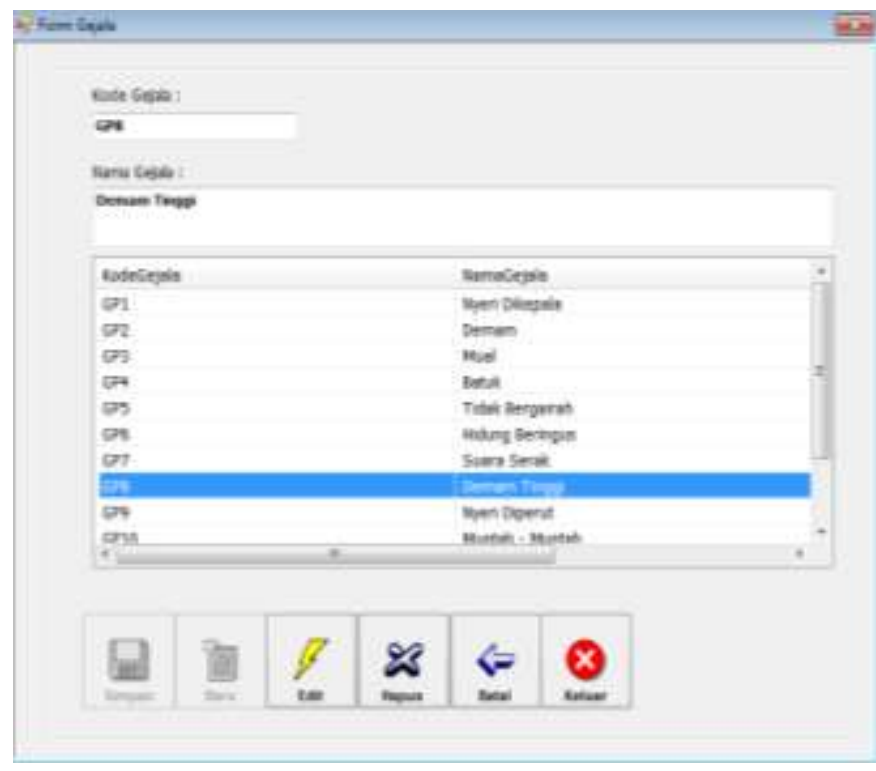

Gambar 2. Tampilan Input Gejala Penyakit

3. Form Konsultasi

Konsultasi dapat dilakukan dengan cara memilih menu "Konsultasi". pada menu ini akan menampilkan hasil dari persentase penyakit. seperti terlihat pada gambar dibawah ini : 


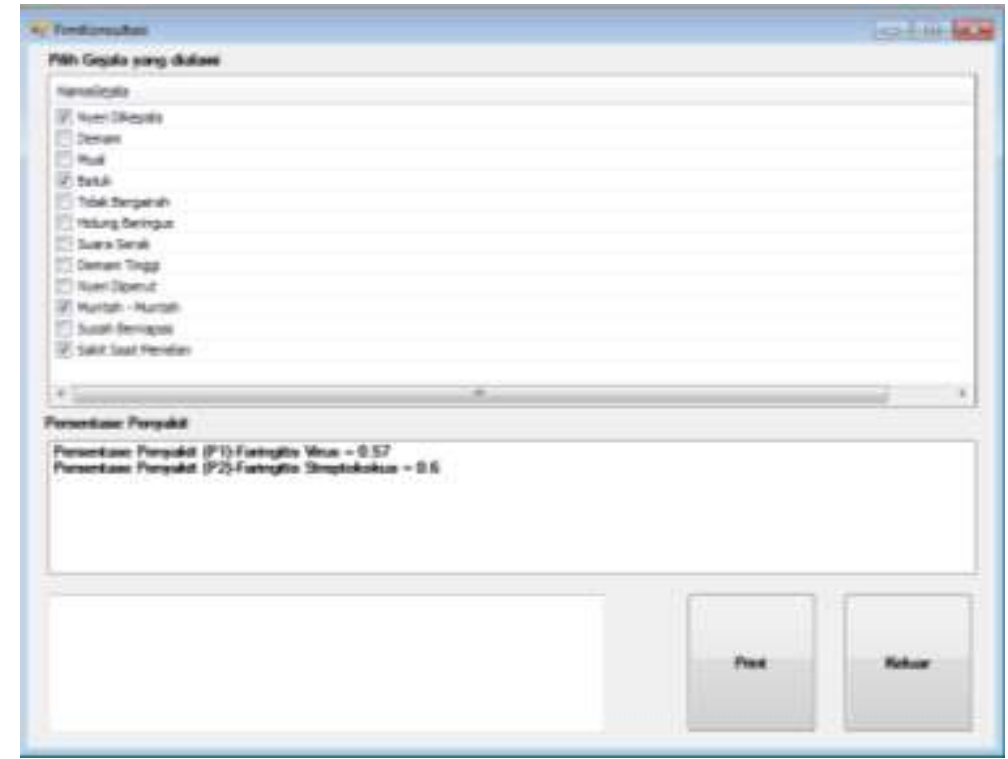

Gambar 3. Tampilan Menu Konsultasi

\section{KESIMPULAN}

Setelah menyelesaikan perangkat lunak sistem pakar diagnosa penyakit faringitis dengan metode dempster shafer, maka dapat ditarik kesimpulan sebagai berikut:

1. Dengan adanya sistem pakar dengan metode dempster shafer maka orang awam pun dapat mengetahui gejala penyakit faringitis tanpa harus bertemu langsung dengan dokter atau ahlinya.

2. Nilai kepercayaan yang dihasilkan dari sistem ini sama dengan hasil perhitungan secara manual dengan menggunakan teori dempster shafer. Sehingga keakuratan hasilnya sudah sesuai dengan perhitungan yang diharapkan.

3. Pencarian tidak selalu menghasilkan solusi. Bila setelah semua keadaan pada pohon pelacakan diperiksa dan dikembangkan dan solusi belum ditemukan, maka permasalahan tidak memiliki solusi.

\section{REFERENCES}

[1] Nur Hidayati, I. 2010. "Pemanfaatan teori bukti dempster shafer untuk optimalisasi penggunaan lahan berdasarkan data spasial dan citra multisumber". Embryo. 7:53-66.

[2] Nur Istiqomah, Y. dan Abdul, F. 2013. "Sistem pakar untuk mendiagnosa penyakit saluran pencernaan menggunakan metode dempster shafer". Jurnal sarjana teknik informatika. 1:32-41.

[3] Wahyuni, E. dan Prijodiprojo, W. 2013. "prototype sistem pakar untuk mendeteksi tingkat resiko penyakit jantung kroner dengan metode dempster shafer". IJCCS. 7:133-144.

[4] Nahampun, M. 2014. "sistem pakar diagnosa penyakit pada tanaman kelapa sawit dengan metode dempster shafer". Pelita Informatika Budidarma. 7:55-59.

[5] Ashari. 2015. "penerapan sistem pakar untuk mengidentifikasi maslah kehamilan dengan metode dempster shafer". Jurnal sarjana teknik informatika. 1:11-16.

[6] Kusumadewi. 2003. Artificial Intelegence. Yogyakarta : Graha Ilmu.

[7] Kusrini. 2006. Sistem Pakar Teori dan Aplikasi. Andi. Yogyakarta.

[8] M. Syahril, N.A. Hasibuan, P. Pristiwanto, PENERAPAN METODE DEMPSTER SHAFER DALAM MENDIAGNOSA PENYAKIT BELL'S PALSY, JURIKOM (Jurnal Ris. Komputer). 3 (2016).

[9] I. Sumatorno, D. Arisandi, A.P.U. Siahaan, M. Mesran, Expert System of Catfish Disease Determinants Using Certainty Factor Method, Int. J. Recent Trends Eng. Res. 3 (2017) 202-209. doi:10.23883/IJRTER.2017.3405.TCYZ2.

[10] N.A. Hasibuan, K. Yusmiarti, F.T. Waruwu, R. Rahim, Expert systems with genetics probability, Int. J. Res. Sci. Eng. 3 (2017) 112116.

[11] M. Mesran, M. Syahrizal, S. Suginam, N. Kurniasih, A.D. Gs, A.S. Ahmar, R. Rahim, Expert System for Disease Risk Based on Lifestyle with Fuzzy Mamdani, Int. J. Eng. Technol. 7 (2018) 88-91. doi:10.14419/ijet.v7i2.3.12622.

[12] Hartono, Jogianto. 2005. Analisis dan Desain Sistem Informasi. Andi. Yogyakarta.

[13] http://kamuskesehatan.com/arti/diagnosis/

[14] https://kruegerchuy.wordpress.com/faringitis/

[15] http://informatika.web.id/teori-dempster-shafer.htm 